Article

\title{
An Assessment Tool to Integrate Sustainability Principles into the Global Supply Chain
}

\author{
María Jesús Muñoz-Torres * (D), María Ángeles Fernández-Izquierdo, Juana M. Rivera-Lirio, \\ Idoya Ferrero-Ferrero ${ }^{(D)}$, Elena Escrig-Olmedo, José Vicente Gisbert-Navarro and \\ María Chiara Marullo \\ Department of Finance and Accounting, Universitat Jaume I, Campus del Riu Sec-Avda. Vicent Sos Baynat s/n, \\ 12071 Castellón de la Plana, Spain; afernand@uji.es (M.Á.F.-I.); jrivera@uji.es (J.M.R.-L.); ferrero@uji.es (I.F.-F.); \\ eescrig@uji.es (E.E.-O.); gisbertj@uji.es (J.V.G.-N.); marullo@uji.es (M.C.M) \\ * Correspondence: munoz@uji.es; Tel.: +34-964-728-572
}

Received: 29 December 2017; Accepted: 14 February 2018; Published: 16 February 2018

\begin{abstract}
The integration of sustainability principles into the assessment of companies along the supply chains is a growing research area. However, there is an absence of a generally accepted method to evaluate corporate sustainability performance (CSP), and the models and frameworks proposed by the literature present various important challenges to be addressed. A systematic literature review on the supply chain at the corporate level has been conducted, analyzing the main strengths and gaps in the sustainability assessment literature. Therefore, this paper aims to contribute to the development of this field by proposing an assessment framework a leading company can adopt to expand sustainability principles to the rest of the members of the supply chain. This proposal is based on best practices and integrates and shares efforts with key initiatives (for instance, the Organizational Environmental Footprint from the European Commission and United Nations Environment Programme and the Society of Environmental Toxicology and Chemistry UNEP/SETAC); moreover, it overcomes important limitations of the current sustainability tools in a supply chain context consistent with the circular economy, the Sustainable Development Goals (SDGs), planetary boundaries, and social foundation requirements. The results obtained create, on the one hand, new opportunities for academics; and, on the other hand, in further research, the use of this framework could be a means of actively engaging companies in their supply chains and of achieving the implementation of practical and comprehensive CSP assessment.
\end{abstract}

Keywords: sustainability principles; corporate sustainability performance (CSP); supply chain; circular economy

\section{Introduction}

Over the past few years, contributing to sustainable development has increasingly become a strategic goal for business and governments. Major initiatives such as the Sustainable Development Goals (SDGs) (see Goal 12) or the EU Sustainable Development Strategy (see key priority challenges) attempt to advance towards sustainable consumption and production patterns. Moreover, the circular economy (CE) concept has risen in importance in the political and business agenda. In parallel, in the academic world, there has been a proliferation of literature on the circular economy model and sustainability, which have become hot topics for research; although the relationship between both concepts and their implementation and assessment have not been studied extensively. In fact, means for the current measurement of sustainability and sustainable development within the new circular economic model remain unclear. Various methodologies have emerged in the last decades to tackle the issue of how business sustainability is measured and assessed. In this context, more challenging 
questions arise: What sort of sustainable development should these assessment structures support? How should sustainability be integrated into supply chains? How should sustainability be measured within the circular economic context? Who is the keystone actor that should implement sustainability principles in practice?

To answer these questions, further research should be developed. This study seeks to contribute to produce solutions by offering an assessment framework a leading company may adopt to expand sustainability principles to the rest of the members of the supply chain.

\subsection{Sustainability Principles}

Sustainable development, which is required to achieve sustainability, is defined in the Anthropocene as "the development that meets the needs of the present while safeguarding Earth's life-support system, on which the welfare of current and future generations depends" [1]. This definition, which is the most widely accepted in the literature, depicts sustainability within a broad and complex context in which it is difficult to operationalize. In this regard, it is fundamental to formulate conceptual principles which explain what sustainability actually means, which will contribute to establishing a basis for action and the essential framework of sustainability [2].

Academics and practitioners have addressed sustainability and sustainable development from different perspectives depending on the core dimension, the type of relationship among them (see, for instance [3]), or the knowledge field (for instance, in law two principles commonly highlighted are environmental integration and the precautionary principle). Likewise, a large number of authors (for example [4-6]) and initiatives (for example the Natural Step Framework) have failed to fully formulate sustainability principles. However, definitions, frameworks or context-dependent principles of sustainability usually address a number of common issues and underlying principles [7] which could be universally applied across different disciplines [8], contributing to the transdisciplinary implementation of the sustainability concept. In the same vein, this study highlights basic and common conceptual principles of sustainability based on seminal references in the sustainability field [9-12] and previous studies focused on sustainability principles [6,13].

The first principle refers to the three dimensions of sustainability (financial economic, environmental, and social), and the balance among them. An initial contribution to the three dimensions of sustainability was the Triple Bottom Line (TBL) concept [9]. The TBL is based on the three inter-linked purposes of economic prosperity (profit), environmental protection (planet), and social equity (people), and seeks to create a balanced performance among the three sustainability dimensions. Nonetheless, when different dimensions are considered, a discussion arises on determining the necessary conditions among them for the achievement of sustainability goals. Originally, this debate dealt with the possibility of the substation between natural capital and manufactured capital $[14,15]$ and, subsequently, it has been extended to the dimensions of sustainability [16-18]. To strike a balance among the three dimensions, the positive results obtained in some of the dimensions cannot hide the poor results achieved in the other dimensions. This implies the integration of the three dimensions, not prioritizing or undermining a dimension over the other ones.

The second principle is based on the inter-generational perspective. This principle comprises the time perspective, which takes into account the long-term effects of today's decisions and a balance between both short- and long-term ones. This perspective implies identifying, evaluating, and managing the risks of current decisions concerning the needs of future generations as well as planning how future generations will be able to meet their needs [19]. Although the most accepted definition of sustainable development [12] explicitly refers to future generation needs, a limited number of initiatives and frameworks include the inter-generational perspective as an explicit principle of sustainability. The second principle, together with the first principle, has been addressed in the literature under the holistic perspective [3], which requires equilibria among economic, environmental, and social aspects in the short-, long- and longer-term perspectives. 
The third principle encompasses the stakeholder approach. Sustainability involves identifying needs of current and future generations [12]. These needs correspond to different groups of stakeholders which may have conflicting interests. At the organizational level, Freeman [10] argues that organizations must bear in mind the different needs and expectations of a variety of stakeholders (not only holders of capital) who can influence the outcome of the organization. This thinking can also be applied to the supply chain, where organizations operate within wider networks of stakeholders. In a win-together approach within the planetary boundaries, organizations should manage their relationships with clients, suppliers, governments, and third-sector organizations, among others. In the stakeholder approach, stakeholder engagement is a fundamental tool for understanding the needs, expectations, and interests of stakeholders.

The fourth principle centers on life cycle thinking (LCT). Sustainability involves a broad set of economic, environmental, and social responsibilities of decision-makers, which cross legal boundaries. Focusing on organizations, their responsibilities should not "stop at the door" and they should also be accountable for the practices of their business partners in the supply chain [11,20]. In this regard, sustainability involves managing the impacts of upstream and downstream activities and, accordingly, the adoption of an LCT approach.

\subsection{Sustainability, Global Supply Chain, and the Circular Economy}

In the last decades, globalization, the role of multinational corporations and group structures in the trade, and the increasing outsourcing to developing countries and low-cost countries have promoted large and complex supply chains comprising companies which vary in size, facilities, resources, profitability, bargaining power, and level of influence. These chains frequently span the globe (manufacturers are usually in the South and retailers and buyers are in the North) and they are integrated by companies that operate in different settings.

Sustainability, in this context, implies that companies identify, assess and manage impacts and risks in all the echelons of the supply chain, taking into account upstream and downstream activities. The academia has contributed to this topic from different areas of research such as the closed-loop supply chain, green supply chains, or sustainable supply chain management (SSCM) [21]. The closed-loop supply chain concept focuses on reverse logistics, that is, taking back the products from customers and recovering added value of the product, components or parts, closing material flows and, consequently, making the shift from a flow economy to a circular economy possible [22]. The green supply chain term aims to integrate environmental concerns, which range from product design and material sourcing and selection to the management of the product end-of-life into the management of supply chain activities [23]. Sustainable supply chain management addresses economic, environmental, and social concerns for the management of material, information and capital flows along the supply chain [24].

Moreover, a common element for the different supply chain configurations and streams of research is to manage the impacts beyond organizational boundaries, acknowledging the full supply chain impacts and risks. However, collecting data beyond the direct suppliers (tier 1) and measuring and managing upstream and downstream impacts pose a significant challenge when it comes to integrating sustainability in the supply chain [25]. Another challenge is related to the complexity of products and the geographical scope of the supply chain [26]. The regions involved in the supply chain are subject to several legal regulations [27]. Moreover, governments tend to offer different degrees of support, depending on the region, to the current linear business since regulations do not address the internalization of the externalities [28] and public procurement does not facilitate the purchase of sustainable products [29].

In order to face these challenges, an appropriate option could be to promote sustainability from a production and consumption system which stimulates the coordination with supply chain companies and the circularity of resource flows. As a consequence, the concept of circular economy has received increased attention in the last years. Although this concept has its antecedents in historical, economic, and ecological fields [30], circular economy is gaining momentum among business practitioners 
(see [31]) and policy makers (see [32,33]). There is no generally accepted definition of circular economy; however, there is a general understanding of the basic characteristics that the circular economy model includes [28]: (i) it is based on closing loops by feeding waste back into production processes and aspires to become a replacement for the linear economic model "take, make and dispose"; (ii) it aims to decouple economic growth from environmental degradation; (iii) it is less dependent on external inputs and outputs and is more resilient; and (iv) it aims to maximize ecosystem function and human well-being, although its relationship with the social dimension is under discussion. In addition, the circular economy regards the supply chain as a critical unit of action for its implementation [28], given the necessity of clear acceptance and support of the model by and for all members of the supply chain.

Circular economy goes beyond organizational boundaries and considers upstream and downstream stages of a product life cycle to operationalize the circularity. Consequently, the supply chain, along with the organizational level, depicts appropriate units of analysis in order to explore the integration of sustainability principles in the circular economy, as well as to examine the operationalization of this relationship.

Current supply chain performance assessment systems are not suitable to integrate the difficulties that are involved when measuring corporate sustainability performance along the supply chain [34]. Therefore, further research is needed to develop more comprehensive corporate sustainability assessment frameworks [35] which can be implemented by the different members along the supply chain and which integrate sustainability principles.

Supply chain management involves different actors and a socio-ecological system which explains tensions and driving forces in the management of the supply chain, and it is the leading company as a keystone actor who influences the structure and processes of the supply chain. Consequently, their decisions could result in cascading effects throughout the socio-ecological system. In this regard, this paper suggests that the leading company should be regarded as a crucial supply chain actor. This actor, with the aim of improving their own performance, through the use of an assessment framework that integrates sustainability principles, can spread sustainability practices along the supply chain and advance towards more sustainable supply chains.

In this context, this study seeks to answer the following research questions: RQ1a-Are sustainability principles integrated in the current circular economy paradigm? and, if not, RQ1b-How could sustainability principles be integrated in the current circular economy paradigm? Finally, there is RQ2-How are sustainability principles being integrated in the assessment of corporate performance along supply chains?

The overall structure of this paper takes the form of five sections including this introduction. Section 2 presents the literature review and its results and Section 3 outlines the sustainability assessment tool proposal. Finally, Section 4 presents the conclusions and suggests avenues for future research.

\section{Literature Review}

This literature review has been carried out using a methodological concept-centric approach based on the key concepts "sustainability" and "supply chain" [36]. In particular, for the first research question the combinations used as a search string in topic were the following: "sustainab *" and "supply chain" / life cycle" and "circular economy". For the second research question, the following combinations were explored: "life cycle assessment" / "circular economy" /"supply chain" and "sustainab * assessment" /"Sustainab* appraisal" and "framework" /" tool*". These concepts were used to carry out the systematic literature review on the academic database Web of Science.

The search was carried out in October 2017 and led to identification of 583 articles, after removing duplicated articles. Subsequently, this study defined the inclusion criteria: (1) the abstract had to demonstrate a clear connection between sustainability principles and circular economy; or the abstract had to present a tool or framework concerning the implementation of sustainability in a circular economy context, or supply chain or life cycle approach; and (2) the article had to be written in English. The exclusion criteria were those studies about: (1) the implementation of the CE in the supply chain 
or life cycle at the macro-level (cities, regions, industries); and (2) technology and process innovation research. Consequently, after a detailed reading of the abstract, those articles which adopted an approach aligned with the exclusion criteria or did not meet the inclusion criteria, were excluded, thereby reducing to 76 the number of articles finally read. In the end, after a careful reading of the identified articles and taking into account the direct inclusion through cross-referencing, 70 articles were selected as relevant publications to develop the theoretical framework of this paper.

To ensure the inclusion of relevant literature, we have applied the same criteria, using the additional keywords "sustainability" or "sustainable" in combination with "circular economy" in the Google Scholar search engine, and after eliminating duplicates, 18 articles were selected in addition as relevant publications.

\subsection{Sustainability Principles and Circular Economy}

Both sustainability and circular economy are concepts which are used by policy makers, practitioners, and academics to integrate environmental and social aspects with economic progress. Surprisingly, very few studies have explored the similarities and differences between them. As an exception, Geissdoerfer et al. [37] conducted a bibliometric research on this topic. Based on the literature review, Geissdoerfer et al. [37] found three general types of relationship between sustainability and circular economy: (i) the circular economy is a condition for sustainability; (ii) the circular economy is an option, among others, that contributes to sustainability; and (iii) the circular economy has potential benefits and costs for sustainability. In these relationships, it is important to note that the circular economy is understood as a factor (explanatory variable) for sustainability, while the integration of both concepts remains largely underexplored.

This study identifies this research gap in order to establish the appropriateness of the circular economy paradigm to integrate sustainability principles into the supply chain. Consequently, the following research question is answered:

\subsubsection{Research Question 1a: Are Sustainability Principles Integrated in the Current Circular Economy Paradigm?}

Regarding the three dimensions of sustainability and the balance among them (Principle 1), literature on circular economy shows a clear consensus on how this paradigm addresses economic and environmental concerns with the aim of optimizing resource yields and preserving and enhancing natural capital (see [38,39]). Regarding the social dimension, a large number of articles contemplate a social goal of circular economy [28,37,38,40-42], mainly based on the creation of new jobs and the reduction of the damage to human utility caused by the current negative externalities. However, as Niero and Hauschild [38] state, these social benefits are the consequences of the actions performed in the other dimensions. In fact, Masi et al. [28] and Murry et al. [30] maintain that the social dimension is less prominent than the others; what is more, they suggest there is no explicit recognition of the social aspects in terms of inter- and intra-generational equity, diversity, financial equality, or equality of social opportunities. Moreover, the balance among dimensions is not integrated in the circular economy model, where the circularity could have a positive influence on the economic and environmental dimensions while adopting, for instance, precarious working conditions [37].

With respect to the inter-generational perspective (Principle 2), the circular economy partially meets this perspective in the economic dimension, since economic growth is based on less dependence on external inputs and more resilience, but there is a lack of results concerning the economic risks and returns in the long term. With respect to the environmental dimension, although the circular economy aims to reduce the extraction of natural resources and foster the use of renewable energy, it is not clear whether the circular economy paradigm maintains the Earth system without contributing to crossing the finite boundaries of the planet [43]. Moreover, Murray et al. [30] criticize the circular economy for having unintended consequences and over-simplistic goals. By way of illustration, Geissdoerfer et al. [37] mention the technical impossibility of a closed circle in combination with a 
growing demand of energy to recycle materials could accelerate global warming causing a major inconvenience than the use of virgin resources. Another gap of the circular economy is the explicit recognition of social equality in terms of generational equity. These results show that circular economy does not take into account the inter-generational perspective in the three dimensions of sustainability.

Focusing on the stakeholder approach (Principle 3), the circular economy attempts to improve customer interaction, loyalty, and satisfaction, offering new business models that establish a longer-term relationship with customers [31]. Although the Ellen MacArthur Foundation [31] also highlights the relevance of the collaborative platforms across sectors between businesses and policymakers as an enabler for the transition towards a circular economy, more efforts should be put in to engage the other stakeholders [28] and to establish coordination mechanisms in the supply chain [27].

Concerning life cycle thinking (Principle 4), the circular economy is associated with the Cradle to Cradle framework [44] which is based on design for reducing the negative impacts of products. In addition, this paradigm maximizes the utility of products, components and materials, promoting the circularity of resources and minimizing leaks, wastage, and losses along the supply chain [30]. Therefore, the circular economy is based on the life cycle thinking in environmental terms since it aims to minimize the environmental impacts of products during their entire life cycle.

These findings provide support for the hypothesis that sustainability principles are not fully integrated in the circular economy model. Hence, this study explores possible ways to make circular economy more sustainable, which leads us to the following research question:

\subsubsection{Research Question 1b: How Could Sustainability Principles be Integrated into the Current} Circular Economy Paradigm?

With the aim of integrating the social dimension into the circular economy, goals which guarantee a minimum of conditions and improvements of the social capital should be explicitly defined. This paper intends to use SDGs as a way of broadening the scope of the circular economy and aligning it with the concept of sustainability.

As far as the inter-generational perspective is concerned, this research proposes considering a framework based on the planetary boundaries framework [43] to address the environmental impact without transgressing the finite boundaries of the planet and to provide a safe operating space for the development of humanity. Focusing on the social dimension, a circular economy could be complemented with the social foundations $[45,46]$ adapted from Oxfam Doughnut to establish the minimum standards of living conditions and human rights necessary for safe and human development. An operationalization of the SDGs is possible through the integrated approach of the planetary boundaries and social foundations.

With respect to the stakeholder approach, more engagement among consumers, government, NGOs and companies is needed [28]. For instance, consumers could participate actively by sharing their solutions and by providing feedback to the system; governments could promote public demand of sustainable products and a greater involvement to support the implementation of circular economy practices; and companies need to collaborate to produce new solutions and share investments and information, building trust between the different echelons of the supply chain. Directly related to this, there is a necessity to improve coordination mechanisms [27], contracts, and financial mechanisms to create links between several supply chain actors and share revenues and risks [47].

Regarding life cycle thinking, there is a critical need to improve decision-support tools that integrate sustainability [25] and adopt a closed-loop orientation in the supply chain management [27]. In this regard, there is room for improvement concerning information and measurement systems from external and internal perspective of the supply chain. From an external perspective, eco-labelling, certifications, comparative ratings, and reporting should provide relevant information to guide sustainable decisions. From an internal perspective, suppliers and buyers should share information to align and clarify misconceptions regarding quality (for example, post-consumer materials to be processed) [47] and manufacturing conditions as well as to connect global measurement systems to manage supply chain 
impacts [25]. With respect to this, there is a clear requisite to advance in the assessment and management systems that integrate the sustainability principles along the supply chain.

\subsection{Sustainability Principles and Corporate Sustainability Assessment along the Supply Chain}

Academia has traditionally analyzed the impact of business activity on sustainable development through the definition and creation of theoretical constructs which attempt to reflect business dynamics in a sustainability context. On the one hand, the so-called corporate social performance was defined as "a set of descriptive categorizations of business activity, focusing on the impacts and outcomes for society, stakeholders and the firm itself" [48,49]. The measurement of corporate social performance has been developed by means of indicators and composite indicators that synthesize relevant social and/or environmental information about company policies, management structures, and outcomes, with the aim of condensing the complexity of a dynamic and polyhedric concept in a manageable amount of information [50]. Abundant literature highlights the difficulties in assessing the social performance to a given organization, due to the nature of the variables that should be considered and to the assessment process itself (see [18,51]). On the other hand, the growing interest of the sustainable development concept resulted in the coinage of the term corporate sustainability performance which is, however, strongly correlated with other corporate social and environmental performance measurement approaches [52].

The main purpose of this study is to formulate a proposal for a corporate sustainability performance assessment framework that will integrate sustainability principles in a circular economy context. Searcy [53] defines a corporate sustainability performance system as "a system of indicators that provides a corporation with information needed to help in the short and long-term management, controlling, planning, and performance of the economic, environmental, and social activities undertaken by the corporation". Going beyond organizations' boundaries, a sustainable performance measurement system could be defined in terms of the environmental and social impacts "of a focal firm and its forward and reverse supply chains over the short and long term" [54]. The assessment of corporate sustainability in a circular economy context goes beyond these definitions; it implies the development of an assessment framework that encourages the minimization of waste and negative economic, social and environmental externalities, and enhances the valorization of economic, social and environmental resources within the system. It could be consistent with what Pope et al. [55] consider an "assessment for sustainability"; yet, under a circular economy context. Consequently, the following research question is asked:

Research Question 2 How are Sustainability Principles being Nowadays Integrated into the Assessment of corporate Performance along Supply Chains?

As noted by previous studies on the basic and common conceptual principles of sustainability, the company sustainability assessment framework: (1) must allow a balance among the economic, social and environmental performance of the company; (2) must integrate the inter-generational perspective; (3) must be based on a stakeholder approach; and (4) must integrate life cycle thinking. Moreover, it must allow the assessment of the economic, social and environmental performance of the company in accordance with the SDGs, planetary boundaries, and social foundations. This section identifies current theoretical frameworks, tools and methods aimed at analyzing corporate sustainability assessment from the point of view of practitioners and academia, and discusses their suitability according to these principles.

Practitioners have been using different tools and initiatives that could be useful in the process of corporate sustainability performance (CSP) assessment. Table 1 summarizes the main international initiatives, standards and tools, which are developed by financial markets, international institutions and multi-stakeholder international organizations, to integrate corporate sustainability into business and to assess CSP; and it shows how these tools are consistent with sustainability principles. For a complete review of these international initiatives and tools, see [56].

The financial market is an important actor for the purpose of achieving sustainable development. On the one hand, public debate on the need for the financial market to be part of the solution to 
the sustainability challenges we face today has advanced in the financial community, civil society, and the media. On the other hand, according to Escrig et al. [57] more and more managers, investors and consumers are becoming aware of the need for sustainable development and, for this reason, they demand accurate financial, environmental, social and governance information (F-ESG data) from the financial market to invest in sustainable companies. In this context, responsible investment plays an important role for the sustainability management of companies [58], leading the process of measuring CSP in operational terms and offering useful information for the decision-making process. However, this measurement process is not exempt of difficulties [58].

Financial market actors such as sustainability rating agencies are active drivers in the development of CSP assessment frameworks. Sustainability rating agencies offer market information on the ability of a company to fulfil its corporate social responsibility commitments. The most representative sustainability rating agencies, considering the number of companies and countries analyzed, are: RobecoSAM's, Vigeo Eiris, FTSE ESG Ratings, MSCI ESG Research, Sustainalytics, Oekom research, and Thomson Reuters ASSET4.

The evaluations of these sustainability rating agencies and indices adopt a stakeholder approach; however, these rating agencies show low convergence in their assessment of CSP [59], and their metrics do not consider some important aspects [18] that could provide a comprehensive and balanced corporate sustainability assessment.

International institutions seek to encourage corporate sustainability [60]. Several multilateral organizations such as the Work Bank, the United Nations, the Organization for Economic Co-operation and Development (OECD), or the European Union have developed different instruments for the integration of corporate sustainability into company management processes and policies which could be useful in the of CSP assessment.

The European Commission promoted the debate on the concept of corporate social responsibility (CSR) in 2001 with the elaboration of the so-called Green Paper which tried to define a European framework for the promotion of CSR. The paradigm of CSR shifted in the "renewed EU strategy 2011-2014 for CSR" of the European Commission. In addition, the follow-up works on these developments are the 2014 Directive on Non-Financial Reporting and the Sustainable Finance initiative. Nowadays, its efforts in sustainability assessment are focused on measuring the environmental impacts of organizations by means of tools such as the Organization Environmental Footprint. The United Nations, through the UN Global Compact, encourages firms to sign up to a set of ten universal principles concerning human rights, labor standards, the environment, and anti-corruption activities. The OECD Guidelines for Multinational Enterprises formulate voluntary principles and standards for responsible business conduct in multiple areas (for instance, labor, human rights, environment, information disclosure, competition, taxation, science and technology, and bribery and corruption).

The initiatives provided by international institutions are mainly based on the assessment of a single dimension or guidelines of voluntary principles and do not reflect an integrated approach as the one presented above.

Finally, a large number of multi-stakeholder international initiatives have been published to help companies to assess their corporate sustainability performance. We can observe that most of them are specialized in one of the sustainability dimensions. In the environmental dimension, some multi-stakeholder initiatives for the implementation of a standardized environmental management system, such as the EMAS and ISO 14001:2015, could be highlighted. The SA8000 and the OHSAS 18001 relate to the social dimension. In recent years, initiatives based on multiple sustainability issues have been designed to integrate CSR management into organizations (for example [11]), or to report about sustainability issues (for instance, the GRI Report Guidelines).

These multi-stakeholder initiatives propose some key environmental and social principles; yet, these initiatives do not devise concrete assessment methods to assess the CSP [61]. Moreover, they address sustainability criteria separating economic, environmental, and social aspects and not in a holistic and integrative way [62]. 
Table 1. Sustainability principles and international initiatives, standards and tools. OECD: Organization for Economic Co-operation and Development; CSR: corporate social responsibility.

\begin{tabular}{|c|c|c|c|c|c|}
\hline Tools and Initiatives & $\begin{array}{l}\text { Sustainability } \\
\text { Dimensions }{ }^{1}\end{array}$ & Balance & $\begin{array}{l}\text { Inter-Generational } \\
\text { Perspective }\end{array}$ & $\begin{array}{l}\text { Stakeholder } \\
\text { Approach }\end{array}$ & Life Cycle Thinking \\
\hline \multicolumn{6}{|c|}{ promoted by financial market } \\
\hline $\begin{array}{l}\text { Sustainability agencies } \\
\text { and indices }\end{array}$ & $\begin{array}{l}\text { EC } \\
\text { EN } \\
\text { SO }\end{array}$ & $x$ & $\neq$ & $\sqrt{ }$ & $x$ \\
\hline \multicolumn{6}{|c|}{ promoted by international institutions } \\
\hline $\begin{array}{c}\text { Organization } \\
\text { Environmental Footprint } \\
{[63]}\end{array}$ & EN & $x$ & $\sqrt{ }$ & $\sqrt{ }$ & $\sqrt{ }$ \\
\hline $\begin{array}{l}\text { UNEP/SETAC Life Cycle } \\
\text { Initiative [64] }\end{array}$ & SO & $x$ & $\sqrt{ }$ & $\sqrt{ }$ & $\sqrt{ }$ \\
\hline $\begin{array}{l}\text { OECD Guidelines for } \\
\text { Multinational Enterprise } \\
\text { [65] }\end{array}$ & $\begin{array}{l}\text { EC } \\
\text { EN } \\
\text { SO }\end{array}$ & - & $\sqrt{ }$ & $x$ & $\sqrt{ }$ \\
\hline UN Global Compact [66] & $\begin{array}{l}\text { EC } \\
\text { EN } \\
\text { SO }\end{array}$ & - & $\sqrt{ }$ & $x$ & $x$ \\
\hline $\begin{array}{l}\text { The UN's Principles for } \\
\text { Responsible Investment } \\
\text { [67] }\end{array}$ & $\begin{array}{l}\text { EC } \\
\text { EN } \\
\text { SO }\end{array}$ & $\sqrt{ }$ & $\sqrt{ }$ & $\sqrt{ }$ & $x$ \\
\hline \multicolumn{6}{|c|}{ promoted by multi-stakeholder international institutions } \\
\hline $\begin{array}{c}\text { AA1000 Assurance } \\
\text { Standard (Accountability) } \\
\text { [68] }\end{array}$ & $\begin{array}{l}\text { EC } \\
\text { EN } \\
\text { SO }\end{array}$ & $x$ & $x$ & $\sqrt{ }$ & $x$ \\
\hline $\begin{array}{l}\text { CDP (the former } \\
\text { CARBON DISCLOSURE } \\
\text { PROJECT) [69] }\end{array}$ & EN & $\mathrm{x}$ & $\sqrt{ }$ & $\sqrt{ }$ & $x$ \\
\hline EMAS certification [70] & EN & $x$ & $\sqrt{ }$ & $\sqrt{ }$ & $\begin{array}{l}\neq \neq \\
\text { Indirect aspects and product life } \\
\text { cycle issues. }\end{array}$ \\
\hline $\begin{array}{l}\text { ISO 1400X [71] } \\
\text { OHSAS 18001 [72] } \\
\text { SA8000 [73] }\end{array}$ & $\begin{array}{l}\text { EN } \\
\text { SO } \\
\text { SO }\end{array}$ & $\begin{array}{l}X \\
- \\
-\end{array}$ & $\begin{array}{l}\sqrt{ } \\
\sqrt{ } \\
\sqrt{ }\end{array}$ & $\begin{array}{l}\sqrt{ } \\
\sqrt{ } \\
\sqrt{ }\end{array}$ & $\begin{array}{l}\sqrt{ } \\
X \\
x\end{array}$ \\
\hline ISO 26000 [11] & $\begin{array}{l}\text { EC } \\
\text { EN } \\
\text { SO }\end{array}$ & $x$ & $\sqrt{ }$ & $\sqrt{ }$ & $\sqrt{ }$ \\
\hline $\begin{array}{l}\text { GRI Report Guidelines G4 } \\
\text { Sustainability Reporting } \\
\text { Guidelines [74] }\end{array}$ & $\begin{array}{l}\text { EC } \\
\text { EN } \\
\text { SO }\end{array}$ & - & $\neq$ & $\sqrt{ }$ & $\begin{array}{c}\neq \\
\text { For some indicators direct }+ \text { indirect } \\
\text { impacts must be accounted }\end{array}$ \\
\hline $\begin{array}{l}\text { International Integrated } \\
\text { Reporting Framework [75] }\end{array}$ & $\begin{array}{l}\text { EC } \\
\text { EN } \\
\text { SO }\end{array}$ & - & $\sqrt{ }$ & $\sqrt{ }$ & $x$ \\
\hline
\end{tabular}

Consequently, practitioners do not have any tools or initiatives which may allow them to fully integrate sustainability principles into the corporate sustainability assessment process. In fact, to our knowledge, although most of the initiatives have gradually integrated the needs and expectations of a variety of stakeholders and risk assessment processes that incorporate the inter-generational perspective, a limited number of initiatives and tools include the TBL balance and life cycle thinking as explicit principles of sustainability. Therefore, there is a clear need to advance in the definition of tools and initiatives that allow practitioners to integrate sustainability principles into the assessment of corporate performance.

From academia, the management of social and environmental issues along the supply chain is gaining momentum [76]; however, several questions arise. In spite of the potential benefits identified in the literature both for corporate performance improvements and across the supply chain [77], the literature review developed by Yawar and Seuring [78] highlights that companies are more interested in the management of social aspects of their supply chain which may have an impact on 
their performance in the short term, and usually overlook those social aspects that may affect the society negatively in the long term. This position is not consistent with sustainability principles, especially with the three dimensions of sustainability and the balance among them, as well as the inter-generational perspective.

Beske-Janssen et al. [79], in their revision about performance measurement in sustainable supply chain management in the last twenty years, draw interesting conclusions regarding questions such as what is measured and how it is measured. As regards to the first question, they conclude that a bias exists in the research published towards economic and environmental aspects; this view is supported by Tajbakhsh and Hassini [34], who found that little attention is paid to social sustainability measures. Despite this, the interest in an economic, social and environmental performance jointly addressed is increasing. As far as the second issue is concerned, the authors conclude that specific metrics regarding how to measure the sustainability performance of supply chains are in their incipient stages. In fact, Yawar and Seuring [78] mention the inexistence of comprehensive indicators for the measurement of social performance in supply chains.

Therefore, the integration of sustainability principles into the supply chain performance assessment in a circular economy context is not only important in itself, but for the whole assessment of the sustainability performance of a company, extending the sustainability assessment process downstream and upstream along the supply chain.

In this context, life cycle assessment (LCA) methodologies are becoming some of the most prevalent approaches for sustainability measurement in the field of supply chain management [79,80], due to their adoption of a full product life cycle perspective which allows an estimate of environmental and social impacts along the entire supply chain. LCA has traditionally been focused on environmental impacts; however, it has evolved into a more inclusive framework which integrates environmental (LCA), social (social life cycle assessment/S-LCA), and economic impacts (by means of life cycle costing/LCC) called life cycle sustainability assessment (LCSA) [64,81] Nevertheless, the level of maturity of social and economic approaches differs from the environmental method, which is more scientifically robust. A classical LCC, based on costs alone, does not integrate aspects associated to long-term economic sustainability in the assessment framework [82]. Moreover, S-LCA is a less developed framework and, despite the fact that tools such as UNEP/SETAC guidelines have been a reference for many researchers [83], it is not possible to identify a generally accepted method for the scientific community [84].

In fact, different assessment frameworks of sustainability performance in supply chains have been established in recent years. Table 2 reports recent frameworks and approaches and analyzes how these frameworks are consistent with sustainability principles. 
Table 2. Sustainability principles and academic proposals. S-LCA: social life cycle assessment; LCC: life cycle costing; MCDM: multiple-criteria decision methods; CLSC: closed-loop supply chain; LCSA:

\begin{tabular}{|c|c|c|c|c|c|c|c|c|}
\hline & Method & Author and Year & Objective & $\begin{array}{l}\text { Sustainability } \\
\text { Dimensions }{ }^{1}\end{array}$ & Balance & $\begin{array}{l}\text { Inter-Generational } \\
\text { Perspective }\end{array}$ & $\begin{array}{l}\text { Stakeholder } \\
\text { Approach }\end{array}$ & $\begin{array}{l}\text { Life Cycle } \\
\text { Thinking }\end{array}$ \\
\hline \multirow{6}{*}{ LCA } & S-LCA & Arcese et al. [85] & $\begin{array}{l}\text { To identify the socioeconomic impact subcategories and the consequent inventory } \\
\text { indicators definition related to the five stakeholders' categories involved in the life } \\
\text { cycle. }\end{array}$ & so & $\mathrm{x}$ & $\mathrm{x}$ & $\checkmark$ & $\sqrt{ }$ \\
\hline & $\begin{array}{l}\text { LCA, LCC, and S-LCA, } \\
\text { MCDM, DEA }\end{array}$ & Halog and Manik [86] & $\begin{array}{l}\text { To develop an integrated methodology by capitalizing the complementary strengths of } \\
\text { different methods used by industrial ecologists and biophysical economists }\end{array}$ & $\begin{array}{l}\text { EC } \\
\text { EN } \\
\text { SO }\end{array}$ & $\checkmark$ & $\mathrm{x}$ & $\checkmark$ & $\checkmark$ \\
\hline & $\begin{array}{l}\text { Social organizational LCA } \\
\text { (SOLCA) }\end{array}$ & $\begin{array}{l}\text { Martínez-Blanco et al. } \\
\text { [87] }\end{array}$ & $\begin{array}{l}\text { To propose a new approach, namely SOLCA and to present its first outline. Main } \\
\text { reference: methodological documents are SLCA (UNEP/SETAC 2009) and OLCA (ISO } \\
\text { 2014; UNEP 2015). }\end{array}$ & so & $\checkmark$ & $\checkmark$ & $\checkmark$ & $\checkmark$ \\
\hline & S-LCA & Tsalis et al. [88] & $\begin{array}{l}\text { To provide a methodological framework for SLCA inspired by the UNEP/ SETAC } \\
\text { guideline, which addresses and evaluates the social profile of companies using } \\
\text { information from sustainability reports. }\end{array}$ & $\begin{array}{l}\text { EC } \\
\text { EN } \\
\text { SO }\end{array}$ & $x$ & $\mathrm{x}$ & $\checkmark$ & $\checkmark$ \\
\hline & LCA & van Kempen et al. [89] & $\begin{array}{l}\text { To contribute to the development of the field by conducting a life cycle sustainability } \\
\text { analysis (LCSA) of sourcing scenarios for a core relief item in a humanitarian supply } \\
\text { chain considering the ReCiPe method and UNEP/ SETAC guideline }\end{array}$ & $\begin{array}{l}\text { EC } \\
\text { EN } \\
\text { SO }\end{array}$ & $x$ & $\checkmark$ & $\checkmark$ & $\checkmark$ \\
\hline & S-LCA & Wang et al. [90] & $\begin{array}{l}\text { To develop a new framework of social life cycle impact assessment (SLCIA) method } \\
\text { based on UNEP/SETAC. }\end{array}$ & so & $x$ & $\checkmark$ & $\checkmark$ & $\checkmark$ \\
\hline \multicolumn{2}{|c|}{$\begin{array}{l}\text { Activity-Based Sustainability (ABS) } \\
\text { integration model }\end{array}$} & $\begin{array}{l}\text { Rodríguez-Olalla and } \\
\text { Avilés-Palacios [91] }\end{array}$ & $\begin{array}{l}\text { To define an ABS integration model that complements other models from an inside-out } \\
\text { perspective. }\end{array}$ & $\begin{array}{l}\text { EC } \\
\text { EN } \\
\text { SO }\end{array}$ & $x$ & $\checkmark$ & $\checkmark$ & $\checkmark$ \\
\hline \multirow{5}{*}{$\begin{array}{l}\text { Multi-criteria } \\
\text { methods } \\
\text { (MCDM) }\end{array}$} & Composite index & $\begin{array}{l}\text { Chardine-Baumann } \\
\text { and Botta-Genoulaz } \\
\text { [61] }\end{array}$ & $\begin{array}{l}\text { To provide a framework for sustainable performance assessment in terms of the } \\
\text { impacts of its SCM practices }\end{array}$ & $\begin{array}{l}\text { EC } \\
\text { EN } \\
\text { SO }\end{array}$ & $\checkmark$ & $\mathrm{x}$ & $x$ & $\checkmark$ \\
\hline & Fuzzy MCDM & Govindan et al. [92] & $\begin{array}{l}\text { To identify an effective model based on the TBL approach for supplier selection } \\
\text { operations in supply chains }\end{array}$ & $\begin{array}{l}\text { EC } \\
\text { EN } \\
\text { SO }\end{array}$ & $\mathrm{x}$ & $\mathrm{x}$ & $\mathrm{x}$ & $\mathrm{x}$ \\
\hline & $\begin{array}{l}\text { Analytic Hierarchy Process } \\
\text { Fuzzy multi-objective } \\
\text { model (FMOM) }\end{array}$ & Govindan et al. [93] & $\begin{array}{l}\text { To present a FMOM aimed at configuring CLSC network design for product recovery, } \\
\text { which integrates supplier selection, flow allocation, and transportation decisions. }\end{array}$ & $\begin{array}{l}\text { EC } \\
\text { EN } \\
\text { SO }\end{array}$ & $\mathrm{x}$ & $x$ & $\sqrt{ }$ & $\mathrm{x}$ \\
\hline & Multi-criteria methods & Souza et al. [94] & $\begin{array}{l}\text { To define a methodological approach for the selection of LCSA impact categories based } \\
\text { on consultation of real stakeholders. }\end{array}$ & $\begin{array}{l}\text { EC } \\
\text { EN } \\
\text { SO }\end{array}$ & $x$ & $\checkmark$ & $\sqrt{ }$ & $\checkmark$ \\
\hline & $\begin{array}{l}\text { Combination of MCDM } \\
\text { (e.g., AHP) }\end{array}$ & Varsei et al. [95] & $\begin{array}{l}\text { To provide a framework which can assist focal companies in the development of } \\
\text { sustainable supply chains. }\end{array}$ & $\begin{array}{l}\text { EC } \\
\text { EN } \\
\text { SO }\end{array}$ & $\mathrm{x}$ & $\mathrm{x}$ & $\checkmark$ & $\mathrm{x}$ \\
\hline \multicolumn{2}{|c|}{ Probabilistic models } & Ahi and Searcy [96] & To provide a probabilistic models for assessing sustainability in the supply chain & $\begin{array}{l}\text { EC } \\
\text { EN } \\
\text { SO }\end{array}$ & $\mathrm{x}$ & $\checkmark$ & $\checkmark$ & $\checkmark$ \\
\hline \multicolumn{2}{|r|}{ DEA } & Bai and Sarkis [97] & $\begin{array}{l}\text { To introduce a methodology to identify sustainable supply chain Key Performace } \\
\text { Indicator (KPI) that can be used for sustainability performance evaluation for suppliers. }\end{array}$ & $\begin{array}{l}\text { EC } \\
\text { EN } \\
\text { SO }\end{array}$ & $\mathrm{x}$ & $\mathrm{x}$ & $\mathrm{x}$ & $\mathrm{x}$ \\
\hline
\end{tabular}


Table 2. Cont.

\begin{tabular}{|c|c|c|c|c|c|c|c|}
\hline Method & Author and Year & Objective & $\begin{array}{l}\text { Sustainability } \\
\text { Dimensions }^{1}\end{array}$ & Balance & $\begin{array}{l}\text { Inter-Generational } \\
\text { Perspective }\end{array}$ & $\begin{array}{l}\text { Stakeholder } \\
\text { Approach }\end{array}$ & $\begin{array}{l}\text { Life Cycle } \\
\text { Thinking }\end{array}$ \\
\hline \multirow{5}{*}{ Supply chain framework } & Beske and Seuring [86] & $\begin{array}{l}\text { To identify key categories of SSCM and related practices that are required to fulfill the } \\
\text { demands of sustainability and, therefore, contributing to sustainability performance. }\end{array}$ & $\begin{array}{l}\text { EC } \\
\text { EN } \\
\text { SO }\end{array}$ & $\mathrm{x}$ & $\sqrt{ }$ & $\checkmark$ & $\checkmark$ \\
\hline & $\underset{[35]}{\text { Hoogmart-ens et al. }}$ & $\begin{array}{l}\text { To present a framework that clarifies the connections and coherence between these existing } \\
\text { assessment tools }\end{array}$ & $\begin{array}{l}\text { EC } \\
\text { EN } \\
\text { SO }\end{array}$ & $\mathrm{x}$ & $\mathrm{x}$ & $\mathrm{x}$ & $\checkmark$ \\
\hline & Schöggl et al. [99] & To provide a conceptual framework for supply chain sustainability assessment. & $\begin{array}{l}\text { EC } \\
\text { EN } \\
\text { SO }\end{array}$ & $\checkmark$ & $\mathrm{x}$ & $\checkmark$ & $\mathrm{x}$ \\
\hline & $\begin{array}{l}\text { Tajbakhsh, and } \\
\text { Hassini, [34] }\end{array}$ & $\begin{array}{l}\text { To analyze the reviewed literature and propose some research questions and indicators for } \\
\text { performance measurement. }\end{array}$ & $\begin{array}{l}\text { EC } \\
\text { EN } \\
\text { SO }\end{array}$ & $\mathrm{x}$ & $\checkmark$ & $\checkmark$ & $\mathrm{x}$ \\
\hline & $\begin{array}{c}\text { Yawar and Seuring } \\
{[78]}\end{array}$ & $\begin{array}{l}\text { To explore the intersection between social issues, CSR actions and performance outcomes, } \\
\text { offering a conceptual framework to the management of social issues in supply chain. }\end{array}$ & $\begin{array}{l}\text { EC } \\
\text { SO }\end{array}$ & $x$ & $x$ & $\checkmark$ & $x$ \\
\hline
\end{tabular}


The main findings of Table 2 confirm that there is a lack of consensus concerning how to assess CSP in the supply chain and only few approaches developed by the academia fully incorporate sustainability principles. Therefore, to develop a CSP assessment framework for the different members of the supply chain, the following challenges should be overcome:

1. The multidimensionality of the sustainability concept makes the search for suitable CSP assessment very difficult [96]. In this context, two main issues must be addressed. On the one hand, although social issues in the supply chain have grown in importance in the last years [78], there is no consensus on the adequate indicators or methods for social assessment [86]. On the other hand, very few proposals, approaches, and frameworks (for example, [98] or [61]) explicitly address a balance among the different sustainability dimensions. To avoid the possible offsetting of negative scores with good scores some authors, such as Escrig-Olmedo et al. [16], and Rivera et al. [100], evaluate the performance in organizations by means of the Fuzzy Inference System methodology.

2. The inter-generational perspective is not considered in the majority of the proposed frameworks, since they do not take into account the interactions of different metrics, outputs, and parameters over time (future) and the long-term effects of today's decisions. However, it is observed that a growing number of different assessment methodologies, such as LCA, are adopting different methods like "hotspots analysis" to prioritize potential actions around the most significant economic, environmental and social sustainability impacts of a company $[87,88]$. In this context, UNEP's Hotspots Analysis Overarching Methodological Framework should be considered in the CSP assessment process.

3. In general terms, there is a lack of integration of stakeholders' interests in decisions on LCSA models. In order to face these challenges, some proposals, like those of Halog and Manik [86] or Souza et al. [94] integrate the stakeholders' preferences through multiple-criteria decision methods. The use of these methodologies, combined with fuzzy logic methods, allows the complete integration of stakeholders' interests [57].

4. Some frameworks are adopting a LCT approach (for instance $[35,86,94]$ ); however, more investigation is needed for advancing into the supply chain management. To overcome this challenge, different tools for monitoring impacts on sustainability like LCA (for example, [85,88]) or footprints methodologies (for instance, [101]) have been developed. In an international context, two of the most accepted methodologies are the Organizational Environmental Footprint from the European Commission, which measures the environmental impacts, and the UNEP/SETAC methodology, which measures social impacts $[88,89]$.

\section{A Corporate Sustainability Assessment Framework Proposal}

This study seeks to increase the strengths and fill gaps identified in the sustainability assessment literature by proposing the integrated assessment tool depicted in Figure 1. The corporate sustainability assessment tool is implemented by a company in the framework of its supply chain management. Ideally, sustainability principles at a meso and macro level should be applied to a supply chain, that is, it should be consistent with the circular economy, the (SDGs) planetary boundaries, and social foundations requirements.

The sustainability assessment tool seeks to provide a framework for the assessment of the environmental, social, and economic impacts on the full supply chain, and for the sustainable management of a company under the principles of sustainability shown in Figure 1 . This framework is structured into five main phases.

In the first phase, the company should establish the basis of the analysis, that is, the company should make the board commitment explicit, determine its objectives, scope and its position within the life cycle, be aware of the existence of its own impacts throughout the life cycle, define its supply chain map, identify its stakeholders, move forward in the valuation process, and plan the sustainability strategy. 
In the second phase, the framework offers footprint methodologies to identify and measure environmental, social and economic impacts. Grounding on the best practices and aligning efforts with key initiatives, the Organizational Environmental Footprint from the European Commission and UNEP/SETAC methodology as tools to measure the environmental and social impacts should be adopted.

In the next phase, the critical points of the company are determined by the application of a hotspots analysis. These hotspots are obtained after the first evaluation of the company and they are kept active all the time until their correction or suppression. To complete this phase, UNEP's Hotspots Analysis Overarching Methodological Framework should be considered.

In the fourth phase, the results obtained in phases 2 and 3 are considered to evaluate sustainability performance. This evaluation is based on fuzzy multi-criteria decision-making methodology, since it allows to overcome the current sustainability assessment limitations $[16,18]$. The outcomes of this phase allow to detect the deficiencies that cause certain scores and to establish concrete objectives for the improvement of sustainable management through the use of corrective measures.

Finally, companies should communicate sustainability results to internal and external stakeholders. These results are associated with the environmental, social and economic performance. Internally, the reporting contributes to setting goals, and managing risks and change more effectively. Externally, transparency about non-financial performance can help to reduce reputational risks, to engage in dialogue with stakeholders, to keep their engagement, and to demonstrate leadership, openness, and accountability.

In addition, for the implementation of this sustainability assessment tool, it is necessary to consider two processes: traceability and assurance. Regarding traceability, the interoperability mechanisms must be defined to ensure this process. The tool should consider traceability of the sustainable management of products, which allows the analysis of the direct and indirect impacts of the company along their value chain. The use of sustainability clauses in contracts in the supply chain and their communication through the entire production process, or the use of sustainable supplier certification programs, are methods to assure traceability. With respect to assurance, all the sustainability assessment processes should contain enough guarantees to provide confidence to the different stakeholders. To this end, in this phase, internal and external auditing processes should be defined.

However, to make this sustainability performance assessment framework effective, it is necessary that a main actor in the supply chain should be in charge. Some studies, like Beske and Seuring [98], highlight that a focal company is usually the most influential and powerful in the supply chain and, therefore, it could be a good initiator of SSCM practices. According to Seuring and Müller [24], to be considered a focal company, a company should: "(i) rule or govern the supply chain; (ii) provide the direct contact to the customer; and (iii) design the product or service offered". In this respect, it is also important that this focal company should be the keystone actor of the supply chain [102], since, in this case, it has a large bargaining power and influence on the rest of the supply chain members. In this scenario, this company is perfectly suitable for becoming a leading company with environmental and social responsibilities. As a leader, it obtains a competitive advantage and is followed and imitated by other organizations, which contributes to spreading this framework to the rest of the industry.

In this context, a leading company could have large influence on the structure and processes of the supply chain and, consequently, their decisions could result in cascading effects throughout the socio-ecological system, making a crucial contribution to sustainable development. Therefore, this leading company could take an essential role to make this sustainability performance assessment framework effective. 


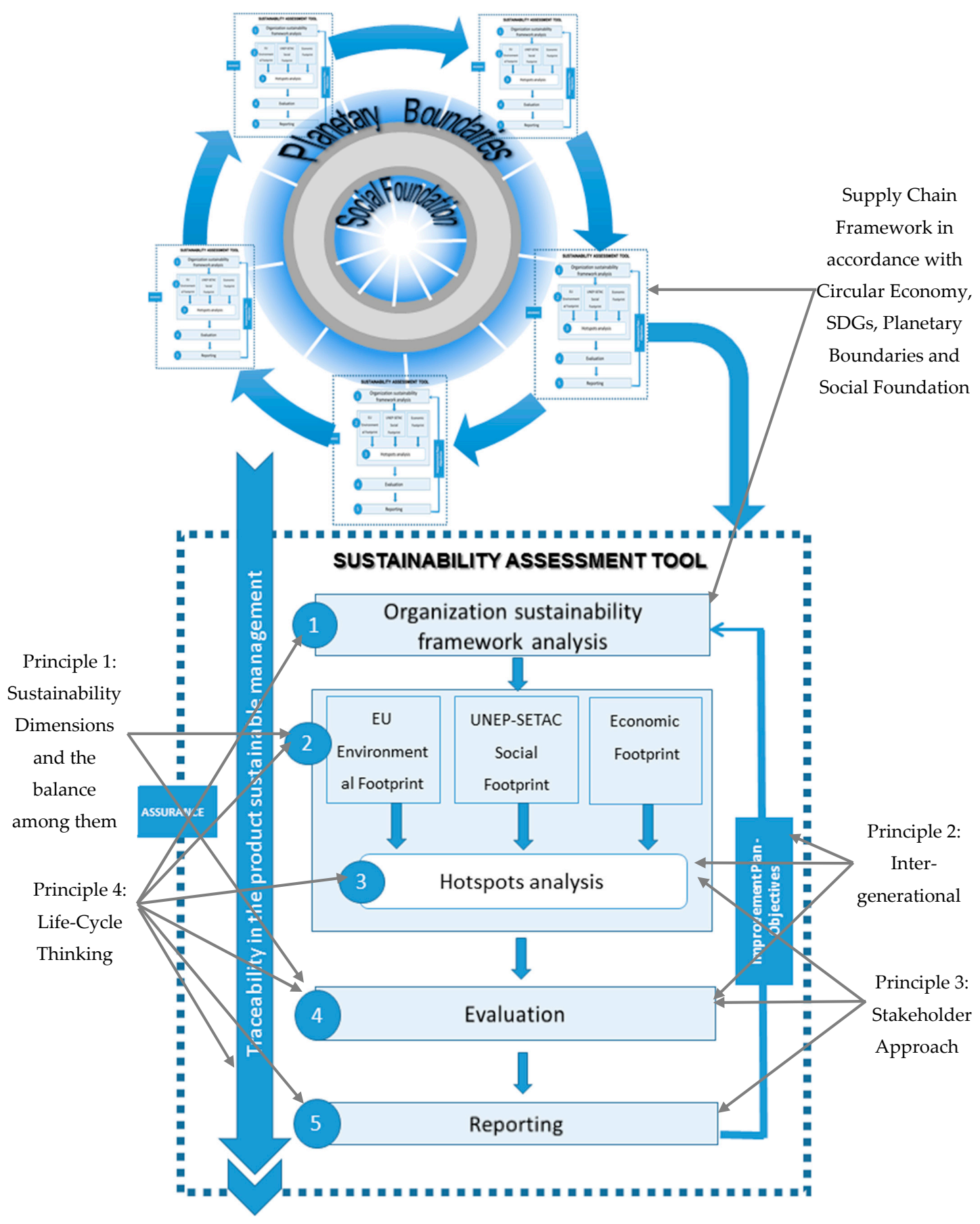

Figure 1. General outline of the sustainability assessment tool. Source: Based on Muñoz-Torres et al. [56] and Melissa et al. [46]. SDGs: Sustainable Development Goals.

\section{Conclusions}

This study aims to thoroughly explore the sustainability assessment in global supply chains by providing an assessment framework a leading company can adopt to expand sustainability principles to the rest of the members of the supply chain. Hence, this paper has carried out a systematic literature review focusing on two stages. First, at the supply chain level, this study has analyzed an ideal system to implement sustainability principles. As a result, the study suggests that the circular economy concept should be positioned within an integrated approach to sustainability and understood as securing social foundations for people everywhere now and in the future, while staying within planetary boundaries. 
Second, this study has reviewed corporate assessment developments to measure sustainability. At this stage, this study has identified gaps and strengths to integrate the four sustainable principles in the assessment methodologies. The main results of the literature review have been considered in the design of the proposal, which is based on the best practices and integrates and shares key initiatives; moreover, it overcomes important limitations of the current sustainability tools. To achieve an effective implementation of this proposal in the whole supply chain, the role of the leading company is crucial. This study suggests that a leading company should adopt this proposal to measure their corporate sustainability performance. In this case, since the leader's performance is affected by the sustainability performance of the rest of the members of the supply chain, their sustainability decisions could result in cascading effects, making a crucial contribution to sustainable development.

Future studies might concentrate on the investigation of the governance model and assurance process. Further research is clearly needed to identify internal and external mechanisms at the top of the companies to foster the discussion and implementation of a real sustainability plan and strategies in the management and assessment of the company. Another important avenue for future studies is to develop an effective assurance system along the whole supply chain, considering both processes and data beyond the confirmation of vague principles.

Acknowledgments: This paper is supported by European Union's Horizon 2020 Research and Innovation Programme under Grant Agreement No. 693642, project SMART (Sustainable Market Actors for Responsible Trade). Moreover, the authors would like to thank the editor and the two anonymous referees for their helpful comments.

Author Contributions: This article is a joint work of the seven authors. María Jesús Muñoz-Torres contributed to research ideas, tools analysis, and assessment tool development as well as the writing of the paper. María Ángeles Fernández-Izquierdo contributed to research ideas, assessment tool development, and decision-making aspects of this paper. Juana M. Rivera-Lirio, Idoya Ferrero-Ferrero, and Elena Escrig-Olmedo contributed to research ideas, literature review, tools analysis, and assessment tool development, as well as the writing of the paper. José Vicente Gisbert-Navarro and María Chiara Marullo contributed to research ideas, tools analysis, and assessment tool development.

Conflicts of Interest: The authors declare no conflict of interest.

\section{References}

1. Griggs, D.; Stafford-Smith, M.; Gaffney, O.; Rockström, J.; Öhman, M.C.; Shyamsundar, P.; Steffen, W.; Glaser, G.; Kanie, N.; Noble, I. Policy: Sustainable development goals for people and planet. Nature 2013, 495, 305-307. [CrossRef] [PubMed]

2. Glavič, P.; Lukman, R. Review of sustainability terms and their definitions. J. Clean. Prod. 2007, 15, 1875-1885. [CrossRef]

3. Lozano, R. Envisioning sustainability three-dimensionally. J. Clean. Prod. 2008, 16, 1838-1846. [CrossRef]

4. Alayón, C.; Säfsten, K.; Johansson, G. Conceptual sustainable production principles in practice: Do they reflect what companies do? J. Clean. Prod. 2017, 141, 693-701. [CrossRef]

5. De Castro Hilsdorf, W.; de Mattos, C.A.; de Campos Maciel, L.O. Principles of sustainability and practices in the heavy-duty vehicle industry: A study of multiple cases. J. Clean. Prod. 2017, 141, 1231-1239. [CrossRef]

6. Silvius, A.G.; Kampinga, M.; Paniagua, S.; Mooi, H. Considering sustainability in project management decision making; An investigation using Q-methodology. Int. J. Proj. Manag. 2017, 35, 1133-1150. [CrossRef]

7. Flint, R.W. Practice of Sustainable Community Development: A Participatory Framework for Change; Springer: New York, NY, USA, 2013.

8. Lindsey, T.C. Sustainable principles: Common values for achieving sustainability. J. Clean. Prod. 2011, 19, 561-565. [CrossRef]

9. Elkington, J. Cannibals with Forks: The Triple Bottom Line of 21st Century Business; Capstone Publishing Ltd.: Oxford, UK, 1997.

10. Freeman, E. Strategic Management: A Stakeholder Approach; Pitman: Boston, MA, USA, 1984.

11. International Organization for Standardization (ISO). International Organization for Standardization, ISO 26000:2010—Guidance on Social Responsibility; ISO: Genève, Switzerland, 2010. 
12. World Commission on Environment and Development (WCED). World Commission on Environment and Development. Our Common Future. 1987. Available online: www.un-documents.net/our-common-future. pdf (accessed on 19 December 2017).

13. Ridsdale, D.R.; Noble, B.F. Assessing sustainable remediation frameworks using sustainability principles. J. Environ. Manag. 2016, 184, 36-44. [CrossRef] [PubMed]

14. Neumayer, E. Weak Versus Strong Sustainability: Exploring the Limits of Two Opposing Paradigms; Edward Elgar Publishing: Cheltenham, UK, 2003.

15. Turner, R.K. Sustainable Environmental Economics and Management: Principles and Practice; Belhaven Press: London, UK, 1993.

16. Escrig-Olmedo, E.; Muñoz-Torres, M.J.; Fernández-Izquierdo, M.Á.; Rivera-Lirio, J.M. Lights \& Shadows on Sustainability Rating Scoring. Rev. Manag. Sci. 2014, 8, 559-574.

17. Ferrero-Ferrero, I.; Fernández-Izquierdo, M.Á.; Muñoz-Torres, M.J. The Effect of Environmental, Social and Governance Consistency on Economic Results. Sustainability 2016, 8, 1005. [CrossRef]

18. Escrig-Olmedo, E.; Muñoz-Torres, M.J.; Fernández-Izquierdo, M.Á.; Rivera-Lirio, J.M. Measuring corporate environmental performance: A methodology for sustainable development. Bus. Strategy Environ. 2017, 26, 142-162. [CrossRef]

19. Boyle, C.; Coates, G.T.K. Sustainability principles and practice for engineers. IEEE Technol. Soc. Mag. 2005, 24, 32-39. [CrossRef]

20. Amaeshi, K.M.; Osuji, O.K.; Nnodim, P. Corporate social responsibility in supply chains of global brands: A boundaryless responsibility? Clarifications, exceptions and implications. J. Bus. Ethics 2008, 81, 223-234. [CrossRef]

21. Andersen, M.; Skjoett-Larsen, T. Corporate social responsibility in global supply chains. Supply Chain Manag. 2009, 14, 75-86. [CrossRef]

22. Guide, V.D.R., Jr.; Van Wassenhove, L.N. The evolution of closed-loop supply chain research. Oper. Res. 2009, 57, 10-18. [CrossRef]

23. Srivastava, S.K. Green supply-chain management: A state-of-the-art literature review. Int. J. Manag. Rev. 2007, 9, 53-80. [CrossRef]

24. Seuring, S.; Müller, M. From a literature review to a conceptual framework for sustainable supply chain management. J. Clean. Prod. 2008, 16, 1699-1710. [CrossRef]

25. O'Rourke, D. The science of sustainable supply chains. Science 2014, 344, 1124-1127. [CrossRef] [PubMed]

26. Hazen, B.T.; Mollenkopf, D.A.; Wang, Y. Remanufacturing for the circular economy: An examination of consumer switching behavior. Bus. Strategy Environ. 2017, 26, 451-464. [CrossRef]

27. Liu, S.; Chang, Y.T. Manufacturers' Closed-Loop Orientation for Green Supply Chain Management. Sustainability 2017, 9, 222. [CrossRef]

28. Masi, D.; Day, S.; Godsell, J. Supply Chain Configurations in the Circular Economy: A Systematic Literature Review. Sustainability 2017, 9, 1602. [CrossRef]

29. Witjes, S.; Lozano, R. Towards a more Circular Economy: Proposing a framework linking sustainable public procurement and sustainable business models. Resour. Conserv. Recycl. 2016, 112, 37-44. [CrossRef]

30. Murray, A.; Skene, K.; Haynes, K. The circular economy: An interdisciplinary exploration of the concept and application in a global context. J. Bus. Ethics 2017, 140, 369-380. [CrossRef]

31. Ellen MacArthur Foundation. Towards a Circular Economy: Business Rationale for an Accelerated Transition. 2015. Available online: https:/ / www.ellenmacarthurfoundation.org (accessed on 22 November 2017).

32. European Commission. Towards a Circular Economy: A Zero Waste Programme for Europe, COM (2014) 398 Final, Brussels, 2014. Available online: http:/ / ec.europa.eu/environment/circular-economy/pdf/circulareconomy-communication.pdf (accessed on 16 February 2018).

33. Su, B.; Heshmati, A.; Geng, Y.; Yu, X. A review of the circular economy in China: Moving from rhetoric to implementation. J. Clean. Prod. 2013, 42, 215-227. [CrossRef]

34. Tajbakhsh, A.; Hassini, E. Performance measurement of sustainable supply chains: A review and research questions. Int. J. Prod. Perform. Manag. 2015, 64, 744-783. [CrossRef]

35. Hoogmartens, R.; Van Passel, S.; Van Acker, K.; Dubois, M. Bridging the gap between LCA, LCC and CBA as sustainability assessment tools. Environ. Impact Asses. 2014, 48, 27-33. [CrossRef]

36. Webster, J.; Watson, R.T. Analyzing the past to prepare for the future: Writing a literature review. MIS Q. $2002,26,13-23$. 
37. Geissdoerfer, M.; Savaget, P.; Bocken, N.M.; Hultink, E.J. The Circular Economy-A new sustainability paradigm? J. Clean. Prod. 2017, 143, 757-768. [CrossRef]

38. Niero, M.; Hauschild, M.Z. Closing the Loop for Packaging: Finding a Framework to Operationalize Circular Economy Strategies. Procedia CIRP 2017, 61, 685-690. [CrossRef]

39. Sauvé, S.; Bernard, S.; Sloan, P. Environmental sciences, sustainable development and circular economy: Alternative concepts for trans-disciplinary research. Environ. Dev. 2016, 17, 48-56. [CrossRef]

40. Loiseau, E.; Saikku, L.; Antikainen, R.; Droste, N.; Hansjürgens, B.; Pitkänen, K.; Leskinen, P.; Kuikman, P.; Thomsen, M. Green economy and related concepts: An overview. J. Clean. Prod. 2016, 139, 361-371. [CrossRef]

41. Korhonen, J.; Honkasalo, A.; Seppälä, J. Circular economy: The concept and its limitations. Ecol. Econ. 2018, 143, 37-46. [CrossRef]

42. Zeng, H.; Chen, X.; Xiao, X.; Zhou, Z. Institutional pressures, sustainable supply chain management, and circular economy capability: Empirical evidence from Chinese eco-industrial park firms. J. Clean. Prod. 2017, 155, 54-65. [CrossRef]

43. Steffen, W.; Richardson, K.; Rockström, J.; Cornell, S.E.; Fetzer, I.; Bennett, E.M.; Biggs, R.; Carpenter, S.R.; de Vries, W.; de Wit, C.A.; et al. Planetary boundaries: Guiding human development on a changing planet. Science 2015, 347, 1259855. [CrossRef] [PubMed]

44. McDonough, W.; Braungart, M. Towards a sustaining architecture for the 21st century: The promise of cradle-to-cradle design. Ind. Environ. 2003, 26, 13-16.

45. Raworth, K. Doughnut Economics: Seven Ways to Think Like a 21st-Century Economist; Chelsea Green Publishing: Chelsea, VT, USA, 2017.

46. Melissa, L.; Raworth, K.; Rockström, J. Between Social and Planetary Boundaries: Navigating Pathways in the Safe and Just Space for Humanity. ISSC and UNESCO World Social Science Report 2013, Changing Global Environments 2013. Available online: http:/ / www.worldsocialscience.org/documents/wss-report-2013part-1.pdf\#page=21 (accessed on 6 February 2018).

47. Fischer, A.; Pascucci, S. Institutional incentives in circular economy transition: The case of material use in the Dutch textile industry. J. Clean. Prod. 2017, 155, 17-32. [CrossRef]

48. Wood, D.J. Corporate social performance revisited. Acad. Manag. Rev. 1991, 16, 691-718.

49. Wood, D.J. Measuring corporate social performance: A review. Int. J. Manag. Rev. 2010, 12, 50-84. [CrossRef]

50. Singh, R.K.; Murty, H.R.; Gupta, S.K.; Dikshit, A.K. An overview of sustainability assessment methodologies. Ecol. Indic. 2009, 9, 189-212. [CrossRef]

51. Roca, L.C.; Searcy, C. An analysis of indicators disclosed in corporate sustainability reporting. J. Clean. Prod. 2012, 20, 103-118. [CrossRef]

52. Morioka, S.N.; de Carvalho, M.M. A systematic literature review towards a conceptual framework for integrating sustainability performance into business. J. Clean. Prod. 2016, 136, 134-146. [CrossRef]

53. Searcy, C. Corporate sustainability performance measurement systems: A review and research agenda. J. Bus. Ethics 2012, 107, 239-253. [CrossRef]

54. Searcy, C. Measuring enterprise sustainability. Bus. Strategy Environ. 2016, 25, 120-133. [CrossRef]

55. Pope, J.; Annandale, D.; Morrison-Saunders, A. Conceptualising sustainability assessment. Environ. Impact Assess. 2004, 24, 595-616. [CrossRef]

56. Muñoz-Torres, M.J.; Fernandez-Izquierdo, M.A.; Rivera-Lirio, J.M.; Ferrero-Ferrero, I.; Escrig-Olmedo, E.; Marullo, M.C.; Gisbert-Navarro, J.V. D5.1 List of Issues to Be Considered under Life Cycle Thinking; Public Report, SMART H2020 Project; 2017. Available online: http:/ / www.smart.uio.no/research/life-cycle-thinking--issues-to-be-considered.pdf (accessed on 14 February 2018).

57. Escrig-Olmedo, E.; Rivera-Lirio, J.M.; Muñoz-Torres, M.J.; Fernández-Izquierdo, M.Á. Integrating multiple ESG investors' preferences into sustainable investment: A fuzzy multicriteria methodological approach. J. Clean. Prod. 2017, 162, 1334-1345. [CrossRef]

58. Busch, T.; Bauer, R.; Orlitzky, M. Sustainable Development and Financial Markets Old Paths and New Avenues. Bus. Soc. 2016, 55, 303-329. [CrossRef]

59. Chatterji, A.K.; Durand, R.; Levine, D.I.; Touboul, S. Do ratings of firms converge? Implications for managers, investors and strategy researchers. Strateg. Manag. J. 2016, 37, 1597-1614. [CrossRef]

60. Antolin-Lopez, R.; Delgado-Ceballos, J.; Montiel, I. Deconstructing corporate sustainability: A comparison of different stakeholder metrics. J. Clean. Prod. 2016, 136, 5-17. [CrossRef] 
61. Chardine-Baumann, E.; Botta-Genoulaz, V. A framework for sustainable performance assessment of supply chain management practices. Comput. Ind. Eng. 2014, 76, 138-147. [CrossRef]

62. Lozano, R.; Huisingh, D. Inter-linking issues and dimensions in sustainability reporting. J. Clean. Prod. 2011, 19, 99-107. [CrossRef]

63. European Commission Joint Research Centre (EC JRC). Organization Environmental Footprint (OEF). 2012. Available online: http:/ / www.eur-lex.europa.eu/legal-content (accessed on 2 November 2017).

64. UNEP/SETAC Life Cycle Initiative. Towards a Life Cycle Sustainability Assessment. Making Informed Choices on Products. 2011. Available online: https://www.uncclearn.org/sites/default/files/unep_ lifecycleinit_dec_final_1.pdf (accessed on 2 November 2017).

65. The Organisation for Economic Co-operation and Development (OECD). Guidelines for Multinational Enterprises; OECD Publishing, 2011. Available online: http://dx.doi.org/10.1787/9789264115415-en (accessed on 2 November 2017).

66. United Nations Global Compact. The Ten Principles of the UN Global Compact. Available online: https: / / www.unglobalcompact.org/what-is-gc/mission/principles (accessed on 2 November 2017).

67. Principles for Responsible Investment (UN's PRI). 2006. Available online: https://www.unpri.org/ (accessed on 2 November 2017).

68. Accountability. AA1000 Accountability Principles Standard (AA1000APS). 2008. Available online: https: / / www.accountability.org/standards/ (accessed on 2 November 2017).

69. Carbon Disclosure Project (CDP). Available online: https:/ / www.cdp.net/ (accessed on 2 November 2017).

70. European Commission (EC). Regulation (EC) No 1221/2009 of the European Parliament and of the Council of 25 November 2009 on the Voluntary Participation by Organisations in a Community Eco-Management and Audit Scheme (EMAS). Available online: http:/ / ec.europa.eu/environment/emas/emas_publications/ policy_en.htm (accessed on 2 November 2017).

71. ISO. International Organization for Standardization, ISO 1400X. Available online: www.iso.org (accessed on 2 November 2017).

72. OHSAS 1. 8001. Available online: https://www.bsigroup.com/en-GB/ohsas-18001-occupational-healthand-safety/ (accessed on 2 November 2017).

73. Social Accountability International (SAI). Social Accountability 8000 International Standard. SA8000. 2014. Available online: http://sa-intl.org/_data/n_0001/resources/live/SA8000\%20Standard\%202014.pdf (accessed on 2 November 2017).

74. Global Reporting Initiative (GRI). G4 Guidelines Part 1: Reporting Principles and Standard Disclosures. 2013. Available online: https: / www.globalreporting.org/resourcelibrary/GRIG4-Part1-Reporting-Principlesand-Standard-Disclosures.pdf (accessed on 2 November 2017).

75. Integrated Reporting (IR). International Integrated Reporting Framework. 2013. Available online: http: / /integratedreporting.org/resource/international-ir-framework/ (accessed on 2 November 2017).

76. Maestrini, V.; Luzzini, D.; Maccarrone, P.; Caniato, F. Supply chain performance measurement systems: A systematic review and research agenda. Int. J. Prod. Econ. 2017, 183, 299-315. [CrossRef]

77. Fritz, M.M.; Schöggl, J.P.; Baumgartner, R.J. Selected sustainability aspects for supply chain data exchange: Towards a supply chain-wide sustainability assessment. J. Clean. Prod. 2017, 141, 587-607. [CrossRef]

78. Yawar, S.A.; Seuring, S. Management of social issues in supply chains: A literature review exploring social issues, actions and performance outcomes. J. Bus. Ethics 2017, 141, 621-643. [CrossRef]

79. Beske-Janssen, P.; Johnson, M.P.; Schaltegger, S. 20 years of performance measurement in sustainable supply chain management-what has been achieved? Supply Chain Manag. 2015, 20, 664-680. [CrossRef]

80. Genovese, A.; Acquaye, A.A.; Figueroa, A.; Koh, S.L. Sustainable supply chain management and the transition towards a circular economy: Evidence and some applications. Omega-Int. J. Manag. S 2017, 66, 344-357. [CrossRef]

81. Onat, N.C.; Kucukvar, M.; Halog, A.; Cloutier, S. Systems Thinking for Life Cycle Sustainability Assessment: A Review of Recent Developments, Applications, and Future Perspectives. Sustainability 2017, 9, 706. [CrossRef]

82. Neugebauer, S.; Forin, S.; Finkbeiner, M. From life cycle costing to economic life cycle assessment-introducing an economic impact pathway. Sustainability 2016, 8, 428. [CrossRef]

83. Wu, R.; Yang, D.; Chen, J. Social life cycle assessment revisited. Sustainability 2014, 6, 4200-4226. [CrossRef] 
84. Chhipi-Shrestha, G.K.; Hewage, K.; Sadiq, R. 'Socializing'sustainability: A critical review on current development status of social life cycle impact assessment method. Clean Technol. Environ. Policy 2015, 17, 579-596. [CrossRef]

85. Arcese, G.; Lucchetti, M.C.; Massa, I. Modeling Social Life Cycle Assessment framework for the Italian wine sector. J. Clean. Prod. 2017, 140, 1027-1036. [CrossRef]

86. Halog, A.; Manik, Y. Advancing integrated systems modelling framework for life cycle sustainability assessment. Sustainability 2011, 3, 469-499. [CrossRef]

87. Martínez-Blanco, J.; Lehmann, A.; Chang, Y.J.; Finkbeiner, M. Social organizational LCA (SOLCA)—A new approach for implementing social LCA. Int. J. Life Cycle Assess. 2015, 20, 1586-1599. [CrossRef]

88. Tsalis, T.; Avramidou, A.; Nikolaou, I.E. A social LCA framework to assess the corporate social profile of companies: Insights from a case study. J. Clean. Prod. 2017, 164, 1665-1676. [CrossRef]

89. Van Kempen, E.A.; Spiliotopoulou, E.; Stojanovski, G.; de Leeuw, S. Using life cycle sustainability assessment to trade off sourcing strategies for humanitarian relief items. Int. J. Life Cycle Assess. 2017, 22, 1718-1730. [CrossRef]

90. Wang, S.W.; Hsu, C.W.; Hu, A.H. An analytic framework for social life cycle impact assessment-Part 1: Methodology. Int. J. Life Cycle Assess. 2016, 21, 1514-1528. [CrossRef]

91. Rodríguez-Olalla, A.; Avilés-Palacios, C. Integrating Sustainability in Organisations: An Activity-Based Sustainability Model. Sustainability 2017, 9, 1072. [CrossRef]

92. Govindan, K.; Khodaverdi, R.; Jafarian, A. A fuzzy multi criteria approach for measuring sustainability performance of a supplier based on triple bottom line approach. J. Clean. Prod. 2013, 47, 345-354. [CrossRef]

93. Govindan, K.; Darbari, J.D.; Agarwal, V.; Jha, P.C. Fuzzy multi-objective approach for optimal selection of suppliers and transportation decisions in an eco-efficient closed loop supply chain network. J. Clean. Prod. 2017, 165, 1598-1619. [CrossRef]

94. Souza, R.G.; Rosenhead, J.; Salhofer, S.P.; Valle, R.A.B.; Lins, M.P.E. Definition of sustainability impact categories based on stakeholder perspectives. J. Clean. Prod. 2015, 105, 41-51. [CrossRef]

95. Varsei, M.; Soosay, C.; Fahimnia, B.; Sarkis, J. Framing sustainability performance of supply chains with multidimensional indicators. Supply Chain Manag. 2014, 19, 242-257. [CrossRef]

96. Ahi, P.; Searcy, C. Assessing sustainability in the supply chain: A triple bottom line approach. Appl. Math. Model. 2015, 39, 2882-2896. [CrossRef]

97. Bai, C.; Sarkis, J. Determining and applying sustainable supplier key performance indicators. Supply Chain Manag. 2014, 19, 275-291. [CrossRef]

98. Beske, P.; Seuring, S. Putting sustainability into supply chain management. Supply Chain Manag. 2014, 19, 322-331. [CrossRef]

99. Schöggl, J.P.; Fritz, M.M.; Baumgartner, R.J. Toward supply chain-wide sustainability assessment: A conceptual framework and an aggregation method to assess supply chain performance. J. Clean. Prod. 2016, 131, 822-835. [CrossRef]

100. Rivera, J.M.; Munoz, M.J.; Moneva, J.M. Revisiting the Relationship between Corporate Stakeholder Commitment and Social and Financial Performance. Sustain. Dev. 2017, 25, 482-494. [CrossRef]

101. Čuček, L.; Klemeš, J.J.; Kravanja, Z. A review of footprint analysis tools for monitoring impacts on sustainability. J. Clean. Prod. 2012, 34, 9-20. [CrossRef]

102. Iansiti, M.; Levien, R. Strategy as ecology. Harv. Bus. Rev. 2004, 82, 68-81. [PubMed]

(C) 2018 by the authors. Licensee MDPI, Basel, Switzerland. This article is an open access article distributed under the terms and conditions of the Creative Commons Attribution (CC BY) license (http://creativecommons.org/licenses/by/4.0/). 